\title{
Building Customers Satisfaction Using Social Responsibility Communications of Islamic Banks in Jordan
}

\author{
Iyad A. Al-Nsour * \\ School of Media and Communication, Department of Advertising and Marketing Communication \\ Al Imam Muhammad ibn Saud Islamic University, Riyadh, KSA.
}

\begin{abstract}
This study aims at diagnosing the impact of social responsibility on satisfaction of Islamic banks' customers in Jordan, then exploring the media means used by such banks to promote the SR programs within local community. Determining the statistical differences in SR, media means and customers satisfaction according to many demographical and organizational factors. This research is descriptive. The questionnaire is the tool of collecting the data needed from research population. The sample size reached to 384 customers, and cluster random sample is used. The study conclude that there is a positive statistical impact of support social responsibility programs on customers satisfaction, but the support social responsibility and customers satisfaction are statistically weak, and the media means used to promote SR programs are traditional and doesn't fit the societal needs. Finally, the study recommends some implications and recommendations that support social responsibility communications and customers' satisfaction in surveyed companies.
\end{abstract}

Keywords: Customers Satisfaction, Social Responsibility, Marketing Communications, Islamic Banks, Jordan. DOI: $10.7176 / \mathrm{NMMC} / 78-03$

\section{Introduction}

The different types of institutions are the main engine of the society development, however, for long time it take the great importance among researchers in different fields of science, especially the various technical and administrative developments. The business firms are looking for differentiation, high market share, and good market position, so they need a lot of administrative, technical and communication skills to reach the desired goals. Therefore, public relations in organizations are an effective and important engine tool that helps such organizations to achieve potential goals and desired performance.

The importance of public relations has grown during the last periods and it has become one of the most important functions of organizations because of the high impact on publics and target audience in both of direct and indirect ways, as well as the rapid developments in the areas internal and external communication. The organizations have strived to build relationships with customers out of organization, and it is quite certain that communication strategy based on PR is sufficient tool for effective collaboration and participation with communities, and it is the easiest way for fruitful and good relations with customers. Public relations don't consider a defensive strategy but it is a curative one aims at making the institution better place for trust, comfort and safety. Thus public relations showing the real face of organization, and as a result it is imperative effort to making better communication, understanding the new opinions of publics and succession of communication strategies.

$\mathrm{SR}$ is one of public relations tools which is become a key engine tool of successful and entrepreneurial business firms worldwide. SR aims at designing the social work strategies which consider as a part of mechanisms and requirements of success for business firms, so the SR is an integral part of profitability measures used in business firms outcomes, and it is activity followed to all levels of management within organization (Caroll, 1999; Smith, 2003). Empirical findings show that organizations don't use the social concepts and values in work strategies, because of such behavior it is quite sure that such organization will face a set of problems and consequences that may affect reputation and relationship of organization with target market, in addition to lower trust and satisfaction levels by local community (Lam, 2016).

Social responsibility describes the extraordinary set of behaviors that businesses should motivate, encourage and provide the incentives that enhance such behaviors in the local communities for deprived segments such the poor and the less developed people (Reichheld\&Schefter, 2000). Social responsibility is also an innovative process through creation sustainable solutions to social problems with specialized and précised considerations , so that the social concept seems a sparkle motivated tool to create the social sustainable values in the communities, and this means that business be able to exploit the opportunities available in this community (Bhattacharya\&Sen,2004;Lam\&Khare,2010). Organizations have actions to meet SR requirements through changing the mechanisms, priorities, programs, models and behaviors used to meet customers' expectations in the target market, and crate value added for VIP customers and shareholders. Drucker (2007) argues that if social action focus on generating the wealth and devolving the economy, so the social responsibility focus on making the world better place for live, work and human capital as well (Lam \& Khare,2010).

Different literatures looking for social responsibility as a part of management, marketing and 
communication sciences; however, the actual traditional modern classification considers SR as a tool within the economic field, which means creation of new industries and business models, redistribution of resources among deprived and neglected segments in local communities. The modern definitions seems social responsibility as a continued institutional activity, and it is sufficient tool to match the social and environmental goals with economic development plans, and in conclusion the larger part of SR benefits focus on the less developed groups in the communities (Lam\&khare,2010).

In this research, social responsibility seems a part of communication and marketing sciences, therefor the roles and responsibilities of businesses in the target market have changed, and it have become a necessary tool to meet and fulfill the interests and needs of stakeholders in ethical and responsible way (Caroll,1999; Fischer,Turner\&Morling,2009). Experiences also show that purchasing decisions have influenced by the social responsibility programs conducted by business firms (Smith, 2003; Castaldo, Perrini, Misani\&Tencati, 2009).

The marketing research have linked between business image and purchasing intentions of customers (Bhattacharya\&Sen, 2004), and the results confirmed the positive relationship between bad practices of social responsibility and the purchasing behavior of customers (Castaldo\&Perrini, 2004). Castaldo et al (2009) have confirmed that there is an impact of social goals of companies on way of thinking for customers towards these companies, and in conclusion the business image and reputation, purchasing preferences of customers, competitive advantage, loyalty, and positive word of mouth will be improved (Lee\&Shin, 2010; Hartmann, 2011; Pérez, Rodríguez del\&Bosque, 2015).

\section{Research Statement:}

Despite of the positive expectations by customers towards the companies that have social responsibility activities (Saleh et al., 2015), but there is long disagreement and discussions about how consumer behavior affected by such activities (Rahim, Jalaludin\&Tajuddin, 2011; Min,Choo, Wah\&Yang, 2012; Safi\&Ramay,2013). Such discussions may be an advantage for current research. This research aims at link between the customers' satisfaction and social responsibility activities conducted by Jordanian Islamic banks. Increasing in the level of education will led to improve the awareness among customers, and the good social practices will enhance also the social values within local communities (Agraqal\& Sahasranamam, 2016).

The economy of Jordan is one of the smallest economies in the Middle East with low quantities of renewable resources such water, agriculture and energy. This situation considers a restricted condition of economic and social development, as well as it seems a pressured factor on the limited resources available, how? The regional political problems have doubled the structural problems in Jordan economy such as poverty, unemployment and budget deficit, and the situation is became more complex for deprived and poor groups of Jordanians and new Syrian refugees as well . The political pressures have reduced the role of official government and local municipalities in economic development, and because of that the developmental traditional priorities of government have changed. The shortages in the financial resources of government increased the volume of debt and the economic reform program is conducted.

In light of above, there is an urgent need for social responsibility practices in Jordan, in order to compensate the role of government in economy. The needs and desires of target audiences have changed. The new development plans focus on the 3D partnerships among government, private and society. The core objectives of Islamic banks in Jordan is crucial part of Islamic texts that looking for encourage and broadcast the Islam values and principles among people in communities. The philosophy of social responsibility is as key priority of Islamic banks in economy of Jordan. It is expected that there is no obstacles may facing social responsibility of Islamic banks in light of high rates of liquidity, deposits amounts reached to $17.6 \%$ of total deposits in banking sector, high rates of profit margins, and high market amounted 54.5\% of total customers in the market for 2017 (Association of Banks In Jordan, 2017).

\section{Research Objectives:}

3.1 Determining the statistical effect of social responsibility programs on customers' satisfaction of Islamic banks in Jordan at the level of significance 0.05 .

3.2 Deterring the statistical differences in the level of social responsibility programs according to media mean used at the level of significance 0.05 .

3.3 Deterring the statistical differences in the level of social responsibility programs according to type of banks, scope of work, and size of the bank at the level of significance 0.05 .

3.4Determining the statistical differences in the level of customers satisfaction according to gender, age, educational level, work type and occupational level at the significance level 0.05 .

\section{Literatures Review:}

\subsection{The Social Responsibility:}

The roots of social responsibility back to fifties of the last century, so the researchers' trials have increased and 
produced more than 477 definitions. So there are many responsible reasons of revolution in social responsibility and caused many changes in attitudes of companies such as: globalization, international blocs and social concept of marketing (Guo, 2009, P.55). Increasing the level of competition in most international markets, unifying the production standards in global market, and lower effectiveness of competitive advantage based on brand strategies are extra factors doubled such revolution (Sen, Bhattacharya\&Korschum, 2006; Gupta, 2002).

Bowen (1953) considered one of the first researchers in the field of social responsibility. He has expressed interest by existence of work policies and systems within companies that provide valuable objective to local society. He also emphasized the need to evaluate the ethical principles and maximize the public interest in the relationship between the company and local working environment. This trend confirmed by many researchers and it aims at emphasize the importance of previous social responsibilities toward society, with not neglecting the financial side of companies as main core objective justify the company's presence in the target market, and therefore the new concepts that support stakeholders and shareholders as customers of business companies are increased also (Jones, 1980).

Manne (1972) considers the companies oriented to community looking for comfort relationship with target people. Boyer (1972) suggests that the relationship between community and company take different forms such as: redistribution of wealth, clean environment, and positive attitude of work. Drucker (1974) suggests that this SR reduces that anxiety of people toward the company. Carson (1977) confirmed that social responsibility support efforts of all participated parties such as customers, academic institutions, businesses leaders and consumer protection movements. Classical school of thought have modified the traditional concept into modern one based on socio-economic change and the need to social programs in local communities.

Group of researchers (Porter, 1995; Hart, 1995; Klassen\&McLaughlin, 1996) have provided valuable contributions that expand the range of social responsibility such as: the relationship between environmental awareness and business performance. The companies environmentally oriented can achieve the competitive advantage by reducing costs, differentiation, positive image, and strategic vision in business plans. Hull and Rothenberg (2008) emphasized the positive relationship between social responsibility and financial performance. Davis (1973) said that the social responsibility will increase legitimacy power in the market. Donaldson (1983) considered the importance of ethical aspects in contractual relations with community, and Hart et al., (2003) have confirmed the correlation between corporate strategies and sustainable values for community and shareholders.

In 1999, the date of conceptual maturity of the social responsibility, carroll described SR as a process aimed at linking among the company goals, welfare of community, positive image and SR programs directed to environment, consumers, employees and stakeholders. Caroll (2008) reacted that advantages of social responsibility in the long run are the best. Petkus and Woodruff added that social responsibility ensures the better work for community (Mohr,Webb Harris,2001).

In 2001, Jensen adds some rights of human, environment and community. Philips and freeman (2001) distinguish between the two types of stakeholders (directly and non- directly affected by company). SR defined by the World Business Council for Sustainable Development (WBCSD,2004) as a commitment by company to achieve the sustainable development, working with employees, corporation with local community. Right now there is no formal determining of social responsibility regulations, but Carroll and Chabana (2010) have determined the four main dimensions of SR : legal and moral obligations (Valor\&delaCuesta,2003; WBCSD,2004;Servaes\&Tamayo,2013), ethical behaviors (Valor\& Del La Cuesta,2003), nonprofit obligations towards special groups of stakeholders (Servaes\& Tamayo,2003; WBCSD,2004), human and environmental rights (Valor\&Del La Cuesta ,2003;Servaes \&Tamayo,2003; WBCSD,2004). Caroll (1979) has agreed with Kolk et al. (2015) that social responsibility has a set of moral and ethical practices (Boateng\&Abdul hamid, 2017).

Finally, there is an agreement that social responsibility has the economic aspect aimed at maximizing the shareholders' value (Kiran\&Sharma,2011), importance of marketing activities based on social aspect such as protecting the environment, developing the community, conserving the resources and charitable donations (Liu\&Zhou,2009). Carroll (1999) is the most prominent researcher who provided a more acceptable and usable framework of social responsibility includes economic, legal, ethical and philanthropic responsibilities (Nochai\&Nochai, 2014; Saleh et al., 2015)

\subsection{Social Responsibility and Customers' Satisfaction in Banks:}

SR is a key tool for success and it is part of marketing strategy of organization (Smith, 2003; Becker, Cudmore\&Hill, 2006; Bhattacharya \& Sen, 2004; Bhattachary a et al., 2009; Hartman, 2011). SR have increased the pressures on business and changed the functions and responsibilities into social innovative means (Bhattachary a et al., 2009). The differentiation and building good relations with customers are core goals of social responsibility SR (Bhattacharya\&Sen, 2004; Milo\& Garrido Morgado, 2012). The higher returns of SR on short and long runs, and improving the consumer responses are reasons to adopt social responsibility. SR has 
new roles in the community such as legal, social and ethical (Onlaor\& Rotchanakitumnuai, 2010). This social responsibility has positive impacts on corporate position, consumer's response, trust, and purchasing intentions (Nochai\&Nochai, 2014).

More specifically, social responsibility programs have many positive effects on a lot of performance variables such as WOM and customer loyalty (Maignan\&Ferrell, 2001). Readiness of consumers' to support social programs and ethical behaviors by companies, and number of visits and quantities purchased also will be increased (Lichtenstein, Drumwright \& Braig, 2004). The positive brand image may be improved as well (Lafferty\& Goldsmith, 2005). Other research confirmed that SR seems a key engine of attracting job seekers, in addition to the positive feelings towards charitable initiatives by company (Strandberg, 2009). As a result the company and brand images become more famous (Sen et al., 2006). For example, SR programs at Massachusetts bank have promoted 138 new accounts amounted \$11 million aimed at endangered spices. Other benefits of CSR consisted of trust in company's advertising, positive support for company disputes with labor or government, and positive word of mouth (Murray\&Vogel, 1997).

The empirical findings have confirmed not only the impact of social responsibility on attracting the customers and increasing business performance evaluation (Sen et al., 2001), but also the on financial success of company (Lee\&Moon, 2008). Thus SR programs become a key source of new opportunities, innovation and competitive advantage as porter et al, in 2006 (Network for Business Sustainability , 2010). The strategic marketing is tool for future making decisions of customer value (Frambach\&Nijssen, 2001), so social responsibility is the prerequisite of understanding and determining the opportunities, enhancing the competitive position, increasing the customers value and retention (Piercy\&Lane,2009). There is strong relationships between diversification of income sources and strategic competitive advantages (IBM, 2008), and the relationship between CSR and customers loyalty are proved (Godfrey\&Hatch, 2007; Hollenbeck \& Kailkati, 2012).

Despite of previous finding, banks are financial devices have roles in promoting economic growth and sound financial performances within financial system (Khan\&Fasih, 2014). For long time, banks have focused on professional and productive banking practices, but the recent research consider the ethical practices in financial industry as a measure of business performance (Lockett, Moon\&Visser,2006). This development explain the new uses of money in social system, so the social performance has an equal percent to financial performance in banking industry.

Social responsibility system consists of economic, social and environmental aspects (Chochol'áková,Gabčová,Belás\&Sipko,2015).The economic aspect can be observed through the traditional role of banks in serving national economy (Belás,Chochol'áková\&Paulík,2014), but other roles can be remarked through developing community and social products such as banking ethics, human rights, charitable activities, environmental policy and social enterprises. Therefore, for more transparency, Social Responsibility practices are creative tool to make the balance between financial and non-financial aspects in banking industry (Yeung, 2011). Credit, assets management, cash inflow and credit risks are considering part of social responsibility of banks affecting the community and business environment (Birindelli et al., 2013). Thus, it is clear now that bank's performance is highly correlated with reputation, degree of certainty, forecasting the future crises and financial performance (Soana, 2011). Ahmad, Islam, and Hassan (2012) highlighted the positive correlation among level of social responsibility and rates of return on assets ROA and equities ROE (Wu\&Xin,2013), and they found the four dimensions of SR have positively affected on legitimacy, employees and owners interests, quality management, and macroeconomic environment. Conversely, high degree of shareholders' equities may be reduced impact of social responsibility (Chih, Chih\&Chen, 2009). Wu and Xin (2013) confirmed the negative correlation between social responsibility and non-performing loans (social charitable loans).

Finally, SR improves the financial performance through reducing costs, increasing productivity, and increasing customers and employees' satisfaction (Loureiro et al., 2012). This satisfaction explains the trust level of customer toward company which is support the future profitable relationship between them. Satisfaction also includes feelings of consumer toward company and its products, and it is consider a strategy aims at increase the effective demand and share of mind as well.

The current research indicate that customer have no any desires to express or define his feelings and level of relationship with company, but there are some practices or behaviors can be expressed this feelings and can be understood within this frame. So Griffin believes that customer satisfaction is a function in many behaviors such as: frequent purchases of products, WOM, pull demand strategy. Not only customer complaints are a distortive way of purchasing rate, financial results and business performance, but also the negative WOM is the most harmful behavior by customers. The core concept of customer dissatisfaction means weak responses by banks to customers' expectations, and the continuous evaluation of banking products and programs is a pressured tool on banks efforts and priorities to understand the changes in customers' preferences on the long run (Grigoroudis et al. 2012). Customer satisfaction is also considered a criterion of assessing the relationship among banks, customers and markets (Munari et al., 2012). Customer satisfaction indicates that the good relationship with 
customers would increase profits (Gupta, 2002). Satisfaction is the engine of banking industry and positively affected on future revenues. The satisfied customer will buy more and positive WOM (Di Matos et al., 2014), while the unsatisfied customer will reduce his purchase (Verbeeten\&Terpstra, 2014). Finally, Social Responsibility initiatives are an effective tool to build customers loyalty, as well as to enhance the customers' awareness toward banks' initiatives. The positive results of social responsibility on customers' satisfaction are proved (Mandhachitaraoolthong, 2011; Hafeez\&Muhammed, 2012).

\section{Research Model:}

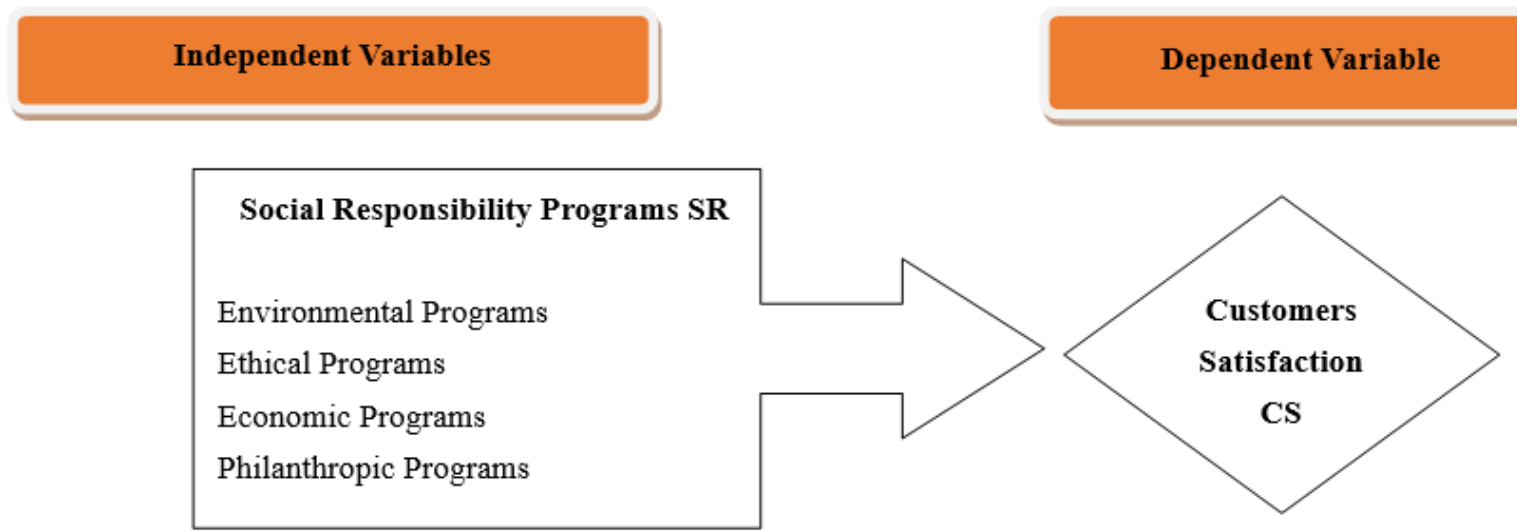

Fig. 1. Research Conceptual Model According to Carol, 1988.

So, the research hypothesis can be formulated as follow:

1.1 $\mathrm{H} 0_{1}$ : There is statistical effect of social responsibility programs on customers satisfaction of Islamic banks in Jordan at the level of significance 0.05 , and there for sub four hypothesis :

- $\mathrm{HO}_{11}$ : The environmental programs have a significant effect on Customers Satisfaction.

- $\mathrm{HO}_{12}$ : The ethical programs have a significant effect on Customers Satisfaction.

- $\mathrm{HO}_{13}$ : The economic programs have a significant effect on Customers Satisfaction.

- $\mathrm{HO}_{14}$ : The philanthropic programs have a significant effect on Customers Satisfaction.

1.2 $\mathrm{HO}_{4}$ : There are statistical differences in the level of social responsibility according to media mean used at the significance level 0.05 .

1.3 $\mathrm{HO}_{2}$ : There are statistical differences in the level of social responsibility programs according to type of bank, scope of work, and size of the bank at the level of significance 0.05 .

1.4 $\mathrm{HO}_{3}$ : There are statistical differences in the level of customers' satisfaction according to gender, age, educational level, work type and occupational level at the significance level 0.05 .

\section{Methodology:}

6.1 Research Design: This study is descriptive. This study aimed at determining the level of social responsibility programs in Islamic banks in Jordan, and investigate the impact of such programs conducted by Islamic banks on customers' satisfaction.

6.2 Research Population: Consists of Islamic and commercial banks customers in Jordan reached to 4083427 in 2016 (Association of banks In Jordan, 2016). In order to calculate the Islamic banks customers only, the exploratory study is conducted which consists of 1000 customers. The main and one question is what kind of banks you dealing with now? The final conclusion shows that $39.1 \%$ of the sample is customers for Islamic banks $(60.9 \%$ is customers for commercial banks). According to last calculations the research population of Islamic banks reached to 1596620 customers (the overall number of customers * Islamic banks share $=4083427$ * $0.391=1596620)$.

6.3 Sampling: The research sample has been withdrew from the customers of Islamic banks in Amman city. The sample size reached to 384 customers, and cluster random sampling method is use.The response rate is $96.6 \%$ of distributed questionnaires, there for the 371 questionnaires are finally analyzed. Unit of Analysis is the customer who deals with Islamic banks in Jordan (for more details about sample look at table7). The research sample is calculated and withdrawal as follow:

A.Estimate the total population of customers based on official statistics for 2016.

B.Conduct the pilot study to determine the elements of the research population according to type of bank (Islamic or non-Islamic bank).

C.Calculate the size of Islamic banks customers in Jordan and determine their demographic characteristics. 
D.Use the relative proportion method in distribution the questionnaire on the Islamic banks customers In Jordan, according to the relative share for each bank of the total Islamic market reached to 1596620 customers.

\subsection{Methods of Data Collection:}

6.4.1 The Secondary Data: It consists of literatures review related to research. The books, theses, dissertations, electronic web sites, and formal reports are used.

6.4.2 The Primary Data: the suitable and correct measurement tool to collect the necessary Primary data for research purposes is the questionnaire.

6.4.2.1 The Measurement: The literatures confirmed the positive impact of social responsibility on customers' satisfaction, otherwise little research that rejected this relationship. This paradox is the base of research statement. In order to answer the research questions and to test the hypotheses, the questionnaire is developed as a mean of data collection of primary data needed. Normality test is used. It measures if the data collected is normally distributed. Statistical rule say that the normality achieved if the significance level less than 0.05 , so according to value of K-S test in table 1, the data used are normally distributed. In addition, the Cronbach's alpha coefficients used. Cronbach's alpha is a measure of internal consistency, that is, how closely related a set of items are as a group. It is considered to be a measure of scale reliability, not a statistical test - it is a coefficient of reliability (or consistency). Cronbach alpha coefficients of all sub research variables are between 0.825- 0.942. This means that the research variables are accepted. Internal consistency of all research variables and are statistically accepted since it is more than the statically permitted rate $60 \%$ (70\% sometimes).

Table1: Measures of Social Responsibility and Customers Satisfaction

\begin{tabular}{|l|l|c|c|c|}
\hline No. & The Variables & Questions & K-S & Cronbach's Alpha \\
\hline 1 & Environmental Programs & $1-5$ & 0.00 & 0.872 \\
\hline 2 & Ethical Programs & $6-10$ & 0.00 & 0.848 \\
\hline 3 & Economic Programs & $11-14$ & 0.00 & 0.825 \\
\hline 4 & Philanthropic Programs & $15-18$ & 0.00 & 0.917 \\
\hline 5 & Customer Satisfaction & $19-25$ & 0.00 & 0.942 \\
\hline 6 & Media Means Used & $26-36$ & 0.00 & 0.834 \\
\hline \multicolumn{2}{|r|}{ Total } & $1-36$ & 0.00 & 0.873 \\
\hline
\end{tabular}

\section{Data Analysis and Results:}

\subsection{Responses Profile:}

The following tables indicate the results of the descriptive statistics of dependent and independent variables. The research used the five-point Likert scale, so number (1) means very low response while number (5) is very high response, and the relative scale is used as follow:

1. 5 - more than 4.2 is very high.

2. 4.2 - more than 3.4 is high.

3. 3.4 -more than -2.4 is medium (acceptable).

4. 2.4 - more than 1.6 is weak.

5. Less than 1.6 is very weak. 
Table 2: Descriptive Statistics of Social Responsibility Programs in Islamic Banks

\begin{tabular}{|c|c|c|c|c|c|c|c|c|c|}
\hline \multirow[t]{2}{*}{ No. } & \multirow[t]{2}{*}{ Phrase } & \multicolumn{5}{|c|}{ Frequencies } & \multirow[t]{2}{*}{ S.D } & \multirow[t]{2}{*}{ Mean } & \multirow[t]{2}{*}{ Decision } \\
\hline & & $\begin{array}{c}\text { Very } \\
\text { Low } \%\end{array}$ & Low $\%$ & Neutral $\%$ & High\% & $\begin{array}{c}\text { Very } \\
\text { High } \%\end{array}$ & & & \\
\hline \multicolumn{2}{|c|}{ First : Environmental Programs } & 38.84 & 39.98 & 17.82 & 1.74 & 3.12 & 0.92609 & 1.7958 & Rejected \\
\hline 1 & $\begin{array}{l}\text { Your Islamic bank has programs of } \\
\text { natural reserves and wildlife. }\end{array}$ & 42.9 & 42.9 & 14.3 & 0 & 0 & 0.7893 & 1.5944 & Rejected \\
\hline 2 & $\begin{array}{l}\text { Your Islamic bank has programs about } \\
\text { the environmental and climate changes. }\end{array}$ & 45.7 & 37.1 & 17.1 & 0 & 0 & 0.8343 & 1.6853 & Rejected \\
\hline 3 & $\begin{array}{l}\text { Your Islamic bank offers programs about } \\
\text { uses and alternative solutions of energy. }\end{array}$ & 37.1 & 37.1 & 17.1 & 2.9 & 5.7 & 1.0193 & 1.9441 & Rejected \\
\hline 4 & $\begin{array}{l}\text { Your Islamic bank has programs about } \\
\text { national heritage. }\end{array}$ & 37.1 & 37.1 & 22.9 & 2.9 & 0 & 0.9685 & 1.8601 & Rejected \\
\hline 5 & $\begin{array}{l}\text { Your Islamic bank provides campaigns } \\
\text { about using and conversation of water } \\
\text { resources. }\end{array}$ & 31.4 & 45.7 & 17.1 & 2.9 & 9.9 & 1.0189 & 1.8951 & Rejected \\
\hline \multicolumn{2}{|c|}{ Second: Ethical Programs } & 30.86 & 34.88 & 24.6 & 5.74 & 4.02 & 1.0311 & 2.0881 & Rejected \\
\hline 6 & $\begin{array}{l}\text { Your Islamic bank has programs about } \\
\text { traffic safety and awareness. }\end{array}$ & 22.9 & 42.9 & 22.9 & 8.6 & 2.9 & 0.9361 & 2.0629 & Rejected \\
\hline 7 & $\begin{array}{l}\text { Your Islamic bank has programs about } \\
\text { shouting in the social events and } \\
\text { occasions. }\end{array}$ & 40 & 34.3 & 22.9 & 2.9 & 0 & 0.9704 & 1.8741 & Rejected \\
\hline 8 & $\begin{array}{l}\text { Your Islamic bank provides programs } \\
\text { about extravagance and opulence in the } \\
\text { social events. }\end{array}$ & 37.1 & 34.3 & 22.9 & 2.9 & 2.9 & 1.0145 & 1.9231 & Rejected \\
\hline 9 & $\begin{array}{l}\text { Your Islamic bank provides a programs } \\
\text { that encourage and support marriage } \\
\text { among youth. }\end{array}$ & 22.9 & 28.6 & 31.4 & 8.6 & 8.6 & 1.197 & 2.5455 & Rejected \\
\hline 10 & $\begin{array}{l}\text { Your Islamic bank provides programs to } \\
\text { motivate Jordanian creators and thinkers }\end{array}$ & 31.4 & 34.3 & 22.9 & 5.7 & 5.7 & 1.0374 & 2.0350 & Rejected \\
\hline \multicolumn{2}{|c|}{ Third : Economic Programs } & 33.55 & 30.7 & 24.27 & 10.02 & 1.45 & 1.08269 & 2.24 & Rejected \\
\hline 11 & $\begin{array}{l}\text { Your Islamic bank provides programs } \\
\text { that support the employment of } \\
\text { Jordanian people. }\end{array}$ & 37.1 & 28.6 & 17.1 & 14.3 & 2.9 & 1.1714 & 2.2238 & Rejected \\
\hline 12 & $\begin{array}{l}\text { Your Islamic bank implements programs } \\
\text { to improve the living levels of poor } \\
\text { people. }\end{array}$ & 34.3 & 31.4 & 25.7 & 8.6 & 0 & 1.0458 & 2.1608 & Rejected \\
\hline 13 & $\begin{array}{l}\text { Your Islamic bank provides programs } \\
\text { that create a great projects of the } \\
\text { economy. }\end{array}$ & 31.4 & 22.9 & 28.6 & 14.3 & 2.9 & 1.1091 & 2.4126 & Rejected \\
\hline 14 & $\begin{array}{l}\text { Your Islamic bank has programs about } \\
\text { the financial and banking security }\end{array}$ & 31.4 & 40 & 25.7 & 2.9 & 0 & 1.0046 & 2.1608 & Rejected \\
\hline \multicolumn{2}{|c|}{ Fourth : Philanthropic Programs } & 38.77 & 34.62 & 18.77 & 6.5 & 1.475 & 0.93561 & 1.9738 & Rejected \\
\hline 1 & $\begin{array}{l}\text { Islamic bank has campaigns that promote } \\
\text { the charity works among Jordanians. }\end{array}$ & 34.3 & 37.1 & 20 & 8.6 & 0 & 0.9031 & 1.9091 & Rejected \\
\hline 2 & $\begin{array}{l}\text { Islamic bank has clean-up campaigns in } \\
\text { the Jordanian cities and villages. }\end{array}$ & 45.7 & 31.4 & 20 & 2.9 & 0 & 0.8889 & 1.8881 & Rejected \\
\hline 3 & $\begin{array}{l}\text { Your Islamic bank organization has } \\
\text { implemented campaigns related to } \\
\text { planting trees in the desert and remote } \\
\text { areas }\end{array}$ & 45.7 & 37.1 & 8.6 & 8.6 & 0 & 0.9381 & 1.8811 & Rejected \\
\hline 4 & $\begin{array}{l}\text { Islamic bank has programs that provide } \\
\text { stationery, books and clothes for poor } \\
\text { people. }\end{array}$ & 29.4 & 32.9 & 26.5 & 5.9 & 5.9 & 1.0950 & 2.2168 & Rejected \\
\hline \multicolumn{2}{|c|}{ Overall Social Responsibility Programs } & 35 & 35.32 & 21.317 & 5.75 & 2.633 & 0.9967 & 2.01515 & Rejected \\
\hline
\end{tabular}

The results in table (2) shows that the respondents customers have rejected all phrases consisted of the social responsibility variable, so this means that the social responsibility programs are not actually applied in the Islamic banks of Jordan, and this result according to the comparison between mean values for each phrase with the mean of scale (3). So the responses degree of social responsibility programs in Islamic banks are weak. Actually, the social responsibility programs have no effect on customers' satisfaction. 
Table3: The Descriptive Statistics of Customers Satisfaction

\begin{tabular}{|c|c|c|c|c|c|c|c|c|c|}
\hline \multirow[t]{2}{*}{ Programs } & \multirow[b]{2}{*}{ Mean } & \multirow[b]{2}{*}{ S.D } & \multicolumn{5}{|c|}{ frequencies } & \multirow{2}{*}{$\begin{array}{l}\text { Level of } \\
\text { Applying }\end{array}$} & \multirow{2}{*}{$\begin{array}{c}\text { Correlation } \\
\text { With SR }\end{array}$} \\
\hline & & & $\begin{array}{l}\text { Strongly } \\
\text { Agree } \%\end{array}$ & Agree $\%$ & $\begin{array}{c}\text { Medium } \\
\%\end{array}$ & $\begin{array}{c}\text { Disagree } \\
\%\end{array}$ & $\begin{array}{c}\text { Strongly } \\
\text { Disagree } \\
\%\end{array}$ & & \\
\hline $\begin{array}{l}\text { Social responsibility } \\
\text { programs conducted by } \\
\text { Islamic banks make me } \\
\text { more trusted of such banks. }\end{array}$ & 2.1429 & 0.8451 & 5.7 & 25.7 & 0 & 45.7 & 22.9 & low & $0.591^{* *}$ \\
\hline $\begin{array}{l}\text { Social responsibility } \\
\text { programs conducted by } \\
\text { Islamic banks motivate me } \\
\text { to buy their products. }\end{array}$ & 2.1714 & 0.8219 & 8.6 & 17 & 0 & 57.1 & 7.1 & low & $0.556^{* *}$ \\
\hline $\begin{array}{l}\text { Social responsibility } \\
\text { programs conducted by } \\
\text { Islamic banks motivate me } \\
\text { to recommend the banks for } \\
\text { relatives and friends. }\end{array}$ & 2.1429 & 0.8451 & 5.7 & 25.7 & 0 & 45.7 & 22.9 & low & $0.499^{* *}$ \\
\hline $\begin{array}{l}\text { Social responsibility } \\
\text { programs conducted by } \\
\text { Islamic banks make me } \\
\text { more proud in such banks. }\end{array}$ & 2.3714 & 1.0869 & 20 & 22.9 & 0 & 31.4 & 25.7 & low & $0.374^{*}$ \\
\hline $\begin{array}{l}\text { Social responsibility } \\
\text { programs conducted by } \\
\text { Islamic banks improve the } \\
\text { image of such banks in the } \\
\text { market. }\end{array}$ & 2.4000 & 0.9761 & 0 & 14.3 & 31.3 & 34.4 & 20 & Low & $0.361^{*}$ \\
\hline $\begin{array}{l}\text { Social responsibility } \\
\text { programs conducted by } \\
\text { Islamic banks increase the } \\
\text { level of desire to work in } \\
\text { such banks. }\end{array}$ & 2.2571 & 1.1464 & 2.9 & 14.3 & 20 & 31.4 & 31.4 & Low & 0.302 \\
\hline $\begin{array}{l}\text { Social responsibility } \\
\text { programs conducted by } \\
\text { Islamic banks make me } \\
\text { satisfied about such banks. }\end{array}$ & 2.3714 & 1.2622 & 8.6 & 8.6 & 25.7 & 25.7 & 31.4 & Low & $0.477^{* *}$ \\
\hline Customers' Satisfaction & 2.2645 & 0.8704 & 11.64 & 18.37 & 11.01 & 38.76 & 20.22 & Low & \\
\hline
\end{tabular}

Correlation is significant at the 0.01 level (2-tailed). $* *$

Correlation is significant at the 0.05 level (2-tailed).*

The results in table (3) shows that there is low level of satisfaction among customers of Islamic banks in Jordan about all phrases Available in the scale, so the customers of Islamic banks are dissatisfied about the social responsibility programs conducted by Islamic banks in Jordan.

Table4: The Descriptive Statistics of Media Means Used To Promote SR Programs

\begin{tabular}{|c|c|c|c|c|c|c|c|c|}
\hline The Mean & $\begin{array}{l}\text { Strongly } \\
\text { Agree } \%\end{array}$ & Agree $\%$ & $\begin{array}{c}\text { Medium } \\
\%\end{array}$ & $\begin{array}{l}\text { Disagree } \\
\%\end{array}$ & $\begin{array}{c}\text { Strongly } \\
\text { Disagree \% }\end{array}$ & S.D & Mean & Decision \\
\hline $\begin{array}{l}\text { Islamic Banks use the newspapers to } \\
\text { promote the SR programs. }\end{array}$ & 4 & 63 & 23 & 10 & 0 & .72328 & 3.61 & Accepted \\
\hline $\begin{array}{l}\text { Islamic Banks use the TV to promote } \\
\text { the SR programs. }\end{array}$ & 0 & 18 & 57 & 23 & 2 & .69769 & 2.91 & Rejected \\
\hline $\begin{array}{l}\text { Islamic Banks use the Radio to promote } \\
\text { the SR programs. }\end{array}$ & 4 & 35 & 42 & 19 & 0 & .80554 & 3.24 & Accepted \\
\hline $\begin{array}{l}\text { Islamic Banks use the official website of } \\
\text { banks to promote the SR programs. }\end{array}$ & 4 & 43 & 53 & 0 & 0 & .57726 & 3.51 & Accepted \\
\hline $\begin{array}{l}\text { Islamic Banks use the outdoor } \\
\text { advertising to promote the SR programs. }\end{array}$ & 19 & 25 & 54 & 2 & 0 & .81520 & 3.61 & Accepted \\
\hline $\begin{array}{l}\text { Islamic Banks use the Internet to } \\
\text { promote the SR programs. }\end{array}$ & 2 & 36 & 46 & 16 & 0 & .74019 & 3.24 & Accepted \\
\hline $\begin{array}{l}\text { Islamic Banks use the text messages to } \\
\text { promote the SR programs. }\end{array}$ & 8 & 26 & 33 & 31 & 2 & .98734 & 3.07 & Accepted \\
\hline $\begin{array}{l}\text { Islamic Banks use the news conferences } \\
\text { to promote the SR programs. }\end{array}$ & 7 & 23 & 36 & 34 & 0 & .92611 & 3.03 & Accepted \\
\hline $\begin{array}{l}\text { Islamic Banks use the social media } \\
\text { means to promote the SR programs. }\end{array}$ & 5 & 25 & 59 & 11 & 0 & .71237 & 3.24 & Accepted \\
\hline $\begin{array}{l}\text { Islamic Banks use the mobile appliances } \\
\text { to promote the SR programs. }\end{array}$ & 0 & 30 & 38 & 32 & 0 & .79111 & 2.98 & Rejected \\
\hline $\begin{array}{l}\text { Islamic Banks use the sales men to } \\
\text { promote the SR programs }\end{array}$ & 19 & 60 & 21 & 0 & 0 & .63532 & 3.98 & Accepted \\
\hline Total & 6.55 & 34.91 & 42 & 16.18 & 0.36364 & 0.76467 & 3.311 & \\
\hline
\end{tabular}

The results in table (4) shows that there is tow media means rejected by customers of Islamic banks in Jordan: TV and mobile appliances. Other means are accepted since by such customers as used means to promote the social responsibility in the target market. The results indicate that level of acceptance by respondent customers towards the media means used by Islamic banks to promote the activities and programs of social responsibility is medium (3.311) with level of standard deviation reached to (0.76467). All the eleven means 
listed in the table 4 , only two means rejected by the respondents: television and mobile applications. Sales men has the first rank, newspapers and outdoor advertising have the second rank, the official website of bank in the third then the social media. TV and mobile applications are the less means used in the communication strategy of Islamic Banks.

These results support the fact that Islamic banks use the traditional mass media, there for the level of customers' awareness toward the bank reputation, products and social activities still low, and this result appears in Spite of the time and efforts consuming to promote the social responsibility programs. It possible for the Islamic banks get the different results when text messages, mobile applications, Social media, and the internet are used to promote SR programs.

\subsection{Testing the Hypotheses:}

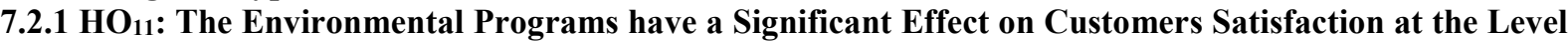
of Significance 0.05 .

The results in table (5) notes that there is no statistical relationship between the environmental programs conducted by Islamic banks in Jordan and customers' satisfaction, so these programs don't explain more than $6.3 \%$ of the variation in customers' satisfaction. The positive correlation between the two variables is poor according to Pearson coefficient (30.2\%). By comparing the tabulated value of significance $(0.05)$ and calculated value of significance of $F$ test (0.078), the first sub-hypothesis is rejected. There is no existence statistical effect of environmental programs offered by Islamic banks in Jordan on customers' satisfaction. Thus the alternative hypothesis is accepted since 0.078 is more than tabulated significance level 0.05 .

7.2.2 HO $_{12}$ : The Ethical Programs Have a Significant Effect on Customers Satisfaction at the Level of Significance 0.05

The results in table (5) shows that there is a middle statistical relationship between the ethical programs conducted by Islamic banks in Jordan and customers satisfaction. These programs have explained $14.6 \%$ of the variation in customers' satisfaction, and the positive correlation between them reached to $41.4 \%$. By comparing the tabulated value of significance $(0.05)$ and calculated value of $F$ test $(0.013)$, the second sub-hypothesis is accepted. So there is statistical effect of ethical programs designed by Islamic banks in Jordan on the customers' satisfaction.

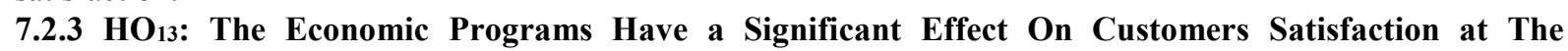
Significance Level 0.05 .

The table (5) indicates that there is an accepted statistical relationship between the economic programs implemented by Islamic banks in Jordan and customers satisfaction. So the economic programs have explained $28 \%$ of the variation in dependent variable (customers satisfaction), and the positive correlation between them reached to $54.8 \%$ By comparing the tabulated level of significance 0.05 and calculated level of significance of $\mathrm{F}$ test $(0.001)$, the first sub-hypothesis is accepted. There is statistical effect of economic programs offered by Islamic banks in Jordan on the customers' satisfaction.

7.2.4 HO14: The Philanthropic Programs Have a Significant Effect On Customers Satisfaction at The Level of Significance 0.05 .

The table (5) shows that there is a poor statistical relationship between the Philanthropic programs conducted by Islamic banks in Jordan and customers satisfaction, so these the lower percent of variation in customers satisfaction $(16.2 \%)$ refers to Philanthropic programs, and the poor positive correlation between reached to 43.1\%. The comparison between the tabulated and calculated values of $\mathrm{F}$ test indicate that the fourth subhypothesis is accepted. So the philanthropic programs conducted by Islamic banks in Jordan affected on the customers satisfaction.

In General, according to results above there are different levels of correlation among social responsibility dimensions that implemented by Islamic banks in Jordan, and level of customers' satisfaction. It is found that there are only three dimensions( out of four) have caused the customers satisfaction, while there is no effect of environmental programs on such and satisfaction. In order to test the first main hypothesis, dependent and independent variables have been formulated in linear equation as follow:

$$
\mathbf{Y}=\mathrm{A}+{ }_{\beta} 1 \mathrm{X} 1+{ }_{\beta} 2 \mathrm{X} 2+{ }_{\beta} 3 \mathrm{X3}+{ }_{\beta} 4 \mathrm{X} 4
$$

Whereas $\mathrm{Y}$ is the dependent variable (customers' satisfaction), while $\mathrm{X} 1, \mathbf{X}_{\mathbf{2}}, \mathbf{X}_{\mathbf{3}}, \mathbf{X}_{\mathbf{4}}$ are dimensions of social responsibility (independent variable): environmental, ethical, economic and philanthropic dimensions respectively. A and B are the parameters. Using SPSS version 23 to estimate the model above as follow:

$$
Y=1.098+0.047 X_{1}-0.3094 X_{2}+0.76 X_{3}-0.059 X_{4}
$$


Table5: Multiple Regression of Social Responsibility Dimensions and Customers Satisfaction.

\begin{tabular}{|l|c|c|c|c|c|c|c|}
\hline Dependent Variable & $\mathrm{R}^{2}$ & $\mathrm{R}$ & $\mathrm{B}$ & $\begin{array}{c}\text { Calculated } \\
\mathrm{F}\end{array}$ & Sig. & $\begin{array}{c}\text { Statistical } \\
\text { Decision }\end{array}$ & The Explanation \\
\hline $\begin{array}{l}\text { Environmental } \\
\text { Programs }\end{array}$ & 0.063 & 0.302 & $\begin{array}{c}0.367 \\
(1.818)\end{array}$ & 3.304 & 0.078 & H0 Is Rejected & $\begin{array}{c}\text { There Is No } \\
\text { Statistical Effect }\end{array}$ \\
\hline Ethical Programs & 0.146 & 0.414 & $\begin{array}{c}0.436 \\
(2.612)\end{array}$ & 6.824 & 0.013 & $\begin{array}{c}\text { H0 Is } \\
\text { Accepted }\end{array}$ & $\begin{array}{c}\text { There Is Statistical } \\
\text { Effect }\end{array}$ \\
\hline Economic Programs & 0.28 & 0.548 & $\begin{array}{c}0.562 \\
(3.768)\end{array}$ & 14.179 & 0.001 & H0 is accepted & $\begin{array}{c}\text { There Is Statistical } \\
\text { Effect }\end{array}$ \\
\hline $\begin{array}{l}\text { Philanthropic } \\
\text { Programs }\end{array}$ & 0.162 & 0.431 & $\begin{array}{c}0.427 \\
(2.748)\end{array}$ & 7.55 & 0.01 & H0 Is & $\begin{array}{c}\text { There Is Statistical } \\
\text { Effect }\end{array}$ \\
\hline
\end{tabular}

-level of significance for the study as a whole is $5 \%$. The value between brackets is the value of t-test of independent variable

The table (5) indicates the relationship between the four dimensions of social responsibility with the dependent variable (customer satisfaction). This analysis indicates that there are three programs have no statistical effects on customers' satisfaction, while the economic programs have the statistical effect on the dependent variable according to calculated and tabulated values of $t$ test. The economic dimension is very important in attracting the new customers. The Islamic banks use and invest the long run deposits, surpluses and financial resources in large scale enterprises. Such enterprises are more visible for economy and it supports the economic growth and social development rather than other enterprises.

The Islamic banks still using the profit and financial criteria in the banking industry, without any considerations or balancing with social aspects. The Islamic banks in Jordan is investing the money surpluses in secured and risk free projects, and looking for added value for shareholders and stakeholders' only. Islamic banks use the Islamic financing methods in financial contracts, and the borrowing is directing to profitable visible enterprises.

This function seems the key mission for banking sector in the economy, but many researchers have emphasizing the urgent need to review and evaluate the ethical norms in such banks, and to maximize the partnership between banks and local communities. This trend has divided into two schools of thinking at the same time, the school of social responsibilities in communities, and the financial school as well. Both of the two schools support the stakeholders and shareholders rights and them looking for increase the business performance results. Finally, the customers' satisfaction in Islamic banks have reducing the market shares and profit margins. This result is confirmed by Nasser (2008) which is indicated that customer satisfaction in the conventional banks greater than such satisfaction in Islamic banks.

It is found that economic programs are the key source of effect on customer satisfaction. Improving economic programs by one unit (JD), will improve the return of customer satisfaction by 0.562 JD, and these programs explain $28 \%$ of changes in customers satisfaction, in addition to the positive accepted relationship between the two variables reached to $54.8 \%$ In order to test the main first hypothesis and using tabulated and calculated values of $\mathrm{F}$ test, the text of hypothesis that say there is a significant statistical effect of social responsibility on customers satisfaction is accepted.

Table6: Results of Testing the First Main Hypothesis

Analysis of The First Hypothesis Using Enter Approach

\begin{tabular}{lcccl}
\hline Variables & $\mathbf{B}$ & $\mathbf{T}$ & Sig. & $\mathrm{F}=3.574$ \\
division A & 1.098 & 2.567 & 0.015 & Sig. $=0.00$ \\
Environmental programs & -0.30944 & 0.225 & 0.823 & $\mathrm{r}=0.568$ \\
Ethical Programs & 0.76 & -0.938 & 0.356 & $\mathrm{R}^{-2}=0.232$ \\
Economic programs & 0.059 & 2.112 & 0.043 & \\
Philanthropic programs & 0.0449 - & 0.26 & 0.797 & \\
Economic Programs & Regression analysis results for the first main hypothesis & \\
& 0.562 & 3.768 & 0.001 & $\mathrm{~F}=14.197$ \\
& & & Sig. $=0.001$ \\
& & & $\mathrm{r}=0.548$ \\
& & & $\mathrm{R}^{-2}=0.28$
\end{tabular}

7.2.5 $\mathrm{HO}_{2}$ : There Are Statistical Differences in Level of Social Responsibility Programs According to Media Mean Used at the Level of Significance 0.05 .

ANOVA analysis is used to determine the statistical differences in level of spreading the social responsibility Programs according to media mean used. The statistical rule says that if the calculated significance level less than 0.05, the main hypothesis will be accepted (Sekaran, 2003, P.243). Table 7 below shows that there are no statistical impact of media means on promoting the social responsibility among customers. This means the all 
media means used have statistically failed in promoting the social responsibility SR programs in the target market, so there is urgent need to evaluate the communication strategy of Islamic banks In Jordan.

Table7: Testing of the Main Second Hypothesis

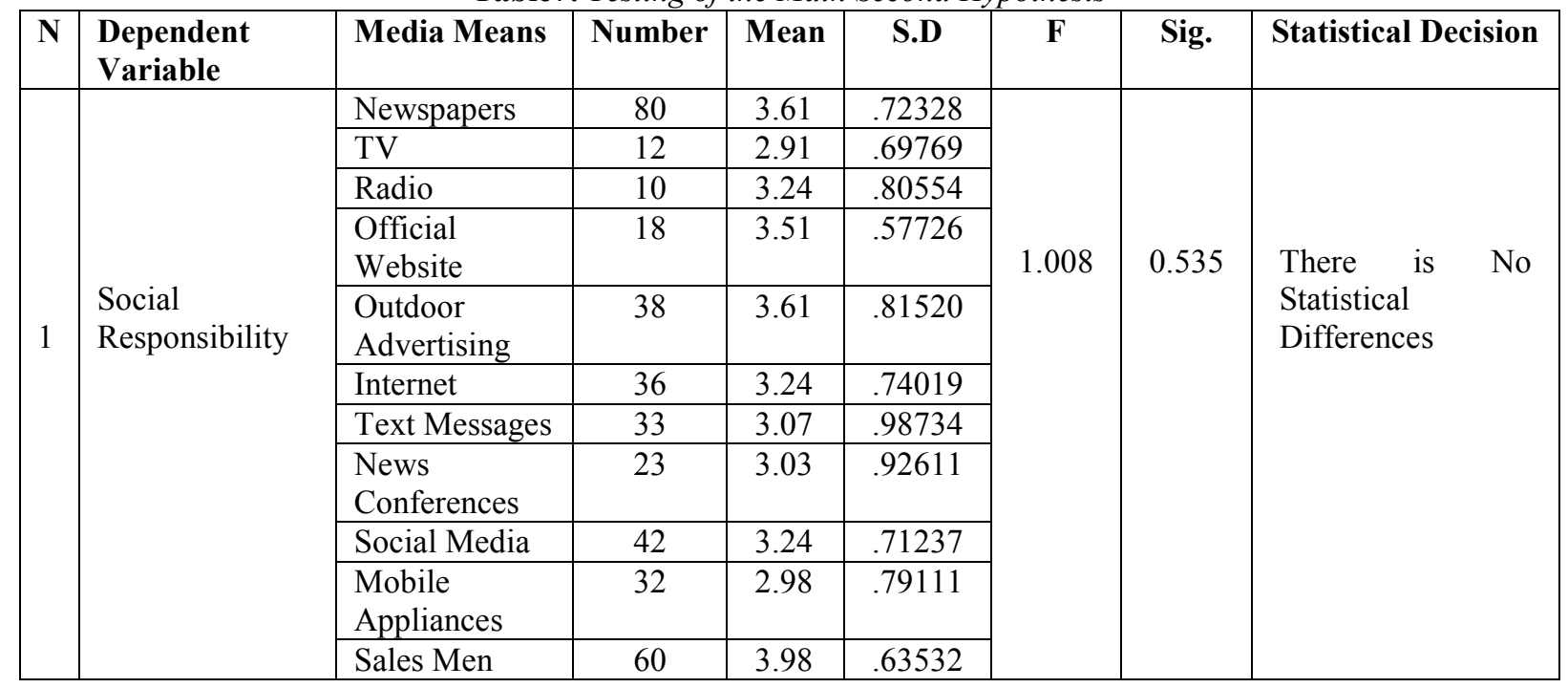

7.2.6 $\mathrm{HO}_{3}$ : There Are Statistical Differences in The Level of Social Responsibility Programs According to type, Name, Size and Scope of Work of banks at the Level of Significance 0.05 .

ANOVA analysis is used to determine the statistical differences in the effect of social responsibility programs according to many organizational factors. The statistical rule says that if the calculated value less than 0.05 , the main hypothesis will be accepted (Sekaran, 2003, P.243). Table 6 shows that there are clear differences in social responsibility programs refers to bank type only: Islamic or conventional. Such statistical differences tend to conventional banks which means that Islamic banks are less efficient in designing the social responsibility programs. According to Scheffe test there are no statistical differences in social responsibility programs according to name of Islamic bank, scope of work, the size of bank.

The Islamic banks are highly restricted and they have functions and roles don't fit the new changes and developments in local communities. The financial prospective is high important function in the Islamic banks, and social values and norms still absent. The Islamic banks consider the main banking functions are the core products in developing the local communities and such functions are embodying the banks responsibility in target market. Not only the financial bonds are the main source of relationship with customers, but also the four golden rules of Islamic banking have urgent need of revision and reevaluation.

Table8: Testing of the Main Second Hypothesis

\begin{tabular}{|c|c|c|c|c|c|c|c|c|}
\hline $\mathbf{N}$ & $\begin{array}{c}\text { Dependent } \\
\text { Variable }\end{array}$ & $\begin{array}{c}\text { The } \\
\text { Character }\end{array}$ & Type & Number & Mean & S.D & $\mathbf{F}$ & Sig. \\
\hline \multirow{12}{*}{1} & \multirow{12}{*}{$\begin{array}{l}\text { Social } \\
\text { Responsibility }\end{array}$} & & Islamic & 21 & 2.0935 & 0.74606 & 4.508 & 0.031 \\
\hline & & The Type & Commercial & 14 & 2.9756 & 0.98754 & & \\
\hline & & & Jordan Islamic Bank & 7 & 1.7821 & 0.48658 & & \\
\hline & & & International Islamic Arab & 9 & 2.3194 & 0.91017 & & \\
\hline & & The & Bank & & & & 0.654 & 0.594 \\
\hline & & Name of & Al-Rajhi Bank & 2 & 1.7375 & 1.04298 & & \\
\hline & & $\begin{array}{c}\text { Islamic } \\
\text { Bank }\end{array}$ & SAFWA Bank & 0 & 0 & 0 & & \\
\hline & & Scope of & Local & 15 & 2.1083 & 0.78191 & & \\
\hline & & Work & International & 2 & 1.7375 & 1.04298 & 0.377 & 0.548 \\
\hline & & & Small & 5 & 1.75 & 0.46829 & & \\
\hline & & & Medium & 9 & 2.3194 & 0.91017 & 1.014 & 0.388 \\
\hline & & Bank Size & Large & 3 & 1.825 & 0.75291 & & \\
\hline
\end{tabular}

7.2.7HO4: There Are Statistical Differences in the Customers Satisfaction According to Gender, Age, Educational Level, Work Type and Occupational Level at the Significance Level 0.05.

ANOVA analysis is used to determine the statistical differences in the customers' satisfaction according to gender, age, educational level, work type and occupational level. The statistical rule says that if the calculated significance level less than 0.05, the main hypothesis will be accepted (Sekaran, 2003, P.243). Table 7 below shows that there are clear no statistical differences in customers' satisfaction according to demographical factors above. 
Table9: Testing of the Main Third Hypothesis

\begin{tabular}{|c|c|c|c|c|c|c|c|c|c|}
\hline \multicolumn{2}{|c|}{$\begin{array}{l}\text { Dependent } \\
\text { Variable }\end{array}$} & \multicolumn{2}{|c|}{ The Character } & Number & $\%$ & Mean & S.D & $\mathbf{F}$ & Sig. \\
\hline \multirow{25}{*}{\multicolumn{2}{|c|}{1 Satisfaction }} & \multirow{4}{*}{ Gender } & Male & 304 & 82 & 2.1143 & 0.78571 & 2.771 & 0.105 \\
\hline & & & Female & 67 & 18 & 2.6429 & 0.99716 & & \\
\hline & & & Less than 20 & 0 & 0 & 0 & 0 & & \\
\hline & & & $20-$ less than 30 & 46 & 12.5 & 2.6071 & 1.084 & & \\
\hline & & \multirow[t]{6}{*}{ Age } & 30 - less than 40 & 141 & 38 & 2.6429 & 0.7398 & & \\
\hline & & & $40-$ less than 50 & 78 & 21 & 2.0143 & 0.92202 & 1.521 & 0.221 \\
\hline & & & 50 -less than 60 & 67 & 18 & 1.9796 & 0.80148 & & \\
\hline & & & +60 & 39 & 10.5 & 1.5714 & 0.60609 & & \\
\hline & & & Secondary & 0 & 0 & 0 & 0 & & \\
\hline & & & School and Less & & & & & & \\
\hline & & \multirow{6}{*}{$\begin{array}{l}\text { Education } \\
\text { Level }\end{array}$} & University & 249 & 67 & 2.4286 & 0.92337 & 1.763 & 0.189 \\
\hline & & & Degree & & & & & & \\
\hline & & & Master Degree & 96 & 26 & 1.5714 & 0.49497 & & \\
\hline & & & $\mathrm{PhD}$ Degree & 26 & 7 & 2.2571 & 0.71524 & & \\
\hline & & & Government & 174 & 47 & 2.4467 & 1.00068 & & \\
\hline & & & Private & 89 & 24 & 1.9524 & 0.29508 & & \\
\hline & & \multirow[t]{5}{*}{ Work Type } & National & 30 & 8 & 2.0714 & 1.5152 & & \\
\hline & & & Philanthropic & 30 & 8 & 2.4286 & 0.60609 & 0.315 & 0.9 \\
\hline & & & Army Forces & 48 & 13 & 2.0816 & 0.84054 & & \\
\hline & & & Employee & 234 & 63 & 2.3968 & 0.8683 & & \\
\hline & & & Head & 82 & 22 & 2.2679 & 1.12599 & & \\
\hline & & \multirow{4}{*}{$\begin{array}{l}\text { Occupational } \\
\text { Level }\end{array}$} & Division & & & & & & \\
\hline & & & Unit Manager & 52 & 14 & 2.9286 & 0.10102 & 0.619 & 0.652 \\
\hline & & & General & 37 & 10 & 1.9143 & 0.56785 & & \\
\hline & & & $\begin{array}{l}\text { Director } \\
\text { Other }\end{array}$ & 4 & 1 & 2.0875 & 0.85237 & & \\
\hline
\end{tabular}

\section{Discussion, Implications and Recommendations \\ 8.1 Findings Discussion}

The results indicate that the level of social responsibility in Islamic banks in Jordan is weak, and on the hand the four sub-dimensions (environmental, ethical, economic, philanthropic) also weak. Social responsibility programs in Islamic banks are responsible about $8.3 \%$ of customers' satisfaction. These results are differ from study of Adamo et al. (2015) which showed that Islamic banks had the positive leadership role in local communities, and this role is determining by new banking products produced and the capability to meet the customers' needs. Current results also differ from study of Almarai et al. which emphasized that Islamic banks have playing an important role in diffusing the social innovation within local market. Despite the high profit margins of Islamic banks in Jordan which reached to $18 \%$ of total banks' profits in Jordan, but such profits have little contributions in the field of social responsibility and social service. The absence of social science in Islamic banks, the lack of specialized units responsible on social responsibility programs, and innovative solutions for new social problems are reasons that explain the weakness in social responsibility initiatives. Here, we are agree with study of Sarath et al. (2013), which have noted that Islamic banks are still unable to improve the target market and they are looking for high profitability rates rather than social issues or problems.

The customer satisfaction of Islamic banks in has low correlation with social responsibility initiatives and such programs has no effect on customer satisfaction. This decline in customer satisfaction is normal result in light of low level of social responsibility in the survived Islamic banks. There is small segment of satisfied respondents (30\%), but the high segment of customers reached to $59 \%$ are dissatisfied about social responsibility programs in the survived banks. The Islamic banks in Jordan have no access to the advantages and benefits available in social responsibility, under this condition, the Islamic banks can't reach to the optimal size of market share and profits margins, so the potential threats and idle opportunities may facing such banks on the long run will be increased. For example, study of Bharuddin et al., (2014) indicates the positive relationship between social responsibility, growth and profits. Group of researchers Chung, Yu, Choi and Shin (2015) they found that low rate of customer satisfaction will decrease the customers' loyalty as well, and both of them are important determinants of growth and profit. Customers' satisfaction requires innovative social products (Chrome, 2015) which enhance the marketing relationship between bank and customer, and encourage the positive partnership between bank and local community (Wulleman\&Hudon, 2015).

Our current results have shown many reasons that decrease the satisfaction of Islamic banks' customers 
such as: lack of positive feelings toward Islamic banks, and negative beliefs of the social role of Islamic banks, the low level of social partnership between banks and local community, the conventional banks have playing a social role exceed Islamic banks, and the profitability measures of Islamic banks are so far from social measures (roles). The current results have emphasized also that social interest rates, lacking of qualified people, low of discrimination between Islamic and conventional banking by central bank laws or regulations, weakness of price and non - price competition between Islamic and conventional banks, and weakness of marketing efforts are threats facing Islamic banks in Jordan. The statistical results have shown the impact of social responsibility programs on the customers' satisfaction in Islamic banks in Jordan, and this results have agreed with many studies that examined this relationship (Fatemifar\&Rahimzadeh, 2015; Humaidan, 2016). The economic programs in Islamic banks are the most influential on customers' satisfaction (Lafi\&Al-Sufy, 2012). Islamic banks can invest the liquidity and cash surpluses in large scale projects, because of such projects are most important for economy. The research results confirms that using of financial measures even social standards will maximize the value added for project owners and shareholders. Many researchers consider the financial standard is reason of staying in the market, but the social expenses consider useless. Our current findings tend to confirm that social responsibility programs have a strong financial impact on corporate performance (Xie, Jia, Meng \& Li, 2017; Sindhu\&Arif, 2017). Staudt, Shao, Dubinsky and Wilson (2014) confirm that social responsibility can generate sustainable financial returns of company through trust, competitive advantage, product value, customer value, customers loyalty and satisfaction, positive WOM (Saleh,Ebeid\&Abdelhameed,2015). The positive social responsibility can also affecting corporate value, positive consumer experience, purchasing behaviors and intentions (Lafferty \& Goldsmith, 2005; Nochai\&Nochai, 2014). Within this discussion, our current results confirm the high correlation among trust of consumers, WOM, customer satisfaction and social responsibility if applied in Islamic banks, but it emphasis that there is no correlation between SR and the desire of job seekers to work in such banks (see table3).

The social responsibility based on environmental programs is completely absent in the Islamic banks in Jordan, so it is consider the most influential engine on customers satisfaction according to Saleem and Gopinath (2015) as well. The less environmental initiatives in banks of India, have destroyed the customer behaviors and purchasing intentions. The study of Paulik, Kombo and Ključnikov (2015) also found that social responsibility programs have a significant impact on satisfaction and loyalty of $87 \%$ of Czech customers, and such results is confirmed by Salazar (2017), in addition to impact of social responsibility on marketing strategy. A lot number of research (Hameed, Rehman \& Ullah, 2017; Irshed, Rahim, Khan\& Khan, 2017; Chun\&Bang, 2016;Chung, Yu, Choi\&Shin, 2015; Hosaini\&Sofian, 2015) confirm the positive impact of SR on customer customers loyalty. Al-Hosaini and Sofian (2015) affirm the impact of SR on customers' awareness toward company and its products. There many researchers also confirm the positive impact of social responsibilities dimensions on satisfaction of Thai telecom customers (Azizi, Saaghi\&Sardo,2014 ; Berg\&Lidfors,2012 ; Onlaor\&Rotchanakitumnuai, 2010), but the one study notes that the economic dimension negatively impacted (Onlaor\&Rotchanakitumnuai, 2010).

This result differs from our current research about in accordance to different in economic environment in both countries. The high scale economic projects in Thailand have reduced the economic effectiveness of social responsibility, but the economic dimension of SR in Jordanian Islamic banks is the main source of competitive advantage and it seem the optimal use of financial surpluses in target market. The study of Fan, Haq,Moeriera and Virk (2018) confirms that economic dimension have negative effect on purchasing intentions of Pakistani customers, but the philanthropic and ethical dimensions have the positive effect on such intentions, and customer satisfaction and retention of Malaysian and Korean customers (Hassan,Nareeman\&Pauline,2017; Park,Kim\&Kwon,2017). In spite of the positive impact of social responsibility, there are many research that reject the relationship between SR and customer satisfaction (Putra\&Yasa, 2017; Behsir\&Eshra, 2017), and increasing the awareness of Egyptian community is sufficient to adopt the SR by local companies.

Current research results examines the level of social responsibility programs among Islamic and conventional banks in Jordan, and it finds that conventional banks have better performance in social respobibilty field, and affairs of Islamic banks is still lower than conventional banks in social work and community service, and it is find that market share, profit margins and other financial indicators are not applicable measures on SR levels in Jordan. It should be noted that Islamic Banks' customers in Jordan are dissatisfied about the social responsibility programs conducting by such banks.

\subsection{Implications and Recommendations}

The results indicate that role of social responsibility in the organizational structure of Islamic banks in Jordan is weak. SR consider an innovative form of communication relations that combined many communicative functions in one. Economic dimension is the corner stone of Islamic banks in promoting social responsibility programs, because of this dimension is the main source of generating the profits and occupying the good position in the minds of shareholders only. Islamic banks believe that their contribution in serving the economy based on 
providing the traditional banking services such as: credit facilities, loans and deposit services, while the three other dimensions of social responsibility are less efficient. The communication strategy of Islamic banks is using the advertising in newspapers and outdoor advertising which accounting $30.7 \%$ of total communication tools used in the strategy.

The communicative dimension of advertising is the most important tool in the promoting the social responsibility programs, despite of the disadvantages of adverting in research and literatures like less interactivity, immediately, direct response, targeting ability, flexibility ... etc. However, the communicative model of advertising remains the most because of the element can't be ignored in any communication strategy of organizations. In the second way, Islamic banks have also used salesmen as part of their communications strategy (15.6\%). The banking service as an intangible good, so it requires interactive face to face contact between the customer and buyer. The personal contact makes it easier to identify customer needs, ensure that the message reaches to the target customer, focuses on profitable customers, and getting the customers feedback. Other tools in the communication strategy are proportionately distributed with a clear conclusion that internet tools $(9.4 \%)$ and social media means $(10.9 \%)$ are idled and unused. In this situation, the communication strategy in Islamic banks has missing one of the most important communicative dimensions in the strategy. It has lost many of the advantages and massive capabilities that the internet provides in the new marketing communication system which combines all traditional marketing communication activities. The Internet is a mean of communication that combines different types of communication: printed, visual and audio media. The internet considers an integrated communication medium that addresses the all human senses together.

Finally, the satisfaction level of Islamic banks' customers has weak degree as well as level of social responsibility programs, and the economic dimension in social responsibility is the main source of the relationship between Islamic banks and society. Overall, the social responsibility dimensions of Islamic banks in Jordan are still less than desired level, so the existing products do not fit the customers' needs and there is no mechanisms and strategies that support the social innovation and community service. So the Islamic banks doesn't exploit the high advantages of social responsibility programs, and therefore such programs are not source of customers' satisfaction. Thus, the high market share and profits margins of Islamic banks in Jordan, are function in emotional loyalty and religious commitment by individuals with halal banking transactions and products. These factors have large contributions in formulating the purchasing decisions and intentions towards Islamic banks in Jordan. The role of marketing and communication strategies in attracting new customers, making profits, and market shares is less developed.

The low rate of customers' satisfaction may not be the most important determinant of social responsibility programs in Islamic banks. The Islamic banks can exploit the emotional loyalty to Islamic banking products explain, so the importance of designing social programs and products that fit the needs and expectations of customers has increased. The importance of Islamic banks is linked with the social meanings and norms that are recognized by Islamic Shari'a, so it is necessary for such banks doubling the efforts consumed to build a better life for customers, enhancing the positive behaviors in society, and well patronage of less developed, deprived and poor groups such as women, aged people, unemployed people, children, orphans and poor families

\section{Research Limitations and Future Research}

This study focus on the social responsibility and customers' satisfaction in the field of Islamic banking in Jordan. The communicative importance of social responsibility in satisfying the customers is the key reason to search in this vital subject. The research limits are the customers of Islamic banks only who living in Amman city in Jordan for year 2017. The Islamic banks is the field of current research. The research focus on the four dimensions of social responsibility according to literatures and previous research. The proposed fields of applying such research are conventional banks, telecom companies, insurance companies, private hospitals, diary companies and Jordan airlines are the engine firms in the economy of Jordan.

\section{Conclusion}

This study aims at determining the impact of social responsibility communications on customers' satisfaction of Islamic banks' in Jordan and exploring the media means used by such banks to promote the SR programs. Islamic banks in Jordan exploit the religious factor and sympathy loyalty to attract the new customers, so the customers' satisfaction in Islamic banks is function in non- physical factors, so it is impossible to determine and affect this satisfaction easily. The low level of social responsibility affected on level of customers' satisfaction. In spite of this results, the Islamic banks are using the less efficient media means in promoting the SR programs. Adverting in newspapers and outdoor means is the most used means in promoting the SR programs. The Internet applications are still idled in the communication strategy of Islamic banks in Jordan. The economic dimension is the source of relationship with local society. The financial and profit measures are the core goals of Islamic banks in local community. Current results noted that Islamic banks should connect their financial performance with Islam legislations that looking for solve the social problems facing young people, aged people, children and 
poor people. This relationship enables such banks to exploit the advantages of SR as well.

\section{References}

Agrawal, A., and Sahasranamam, A. (2016) “Corporate social entrepreneurship in India', South Asian Journal of Global Business Research, 5 (2), 214-233, https://doi.org/10.1108/SAJGBR-12-2014-0098.

Ahmed, S. U., Islam, M. Z., Hasan, I. (2012), 'CSR and Financial Performance Linkage-Evidence from the Banking Sector of Bangladesh, 'J. Org. Management, 1(1), 14-21.

Association of Banks In Jordan. Annual Report. Amman. 2017.

Becker-Olsen, K., Cudmore, A., and Hill, R. (2006), "The impact of perceived corporate social responsibility on consumer behavior", Journal of Business Research, 59(1).46-53.

Behsir, N., and Eshra, N. (2017), "Impact of Corporate Social Responsibility on Consumer Buying Behavior in Egypt" World Review of Business Research, 7(1), 32-44.

Belás, J., Chocholáková, A., and Paulík, J. (2014),"Social responsibility, ethics, satisfaction in the banking business: A case study from Slovak and Czech Republic", 1 Saarbrucken: Lap Publishing.

Beyer, R. (1972), “The 'Bottom Line' is no longer where it's at; an accounting executive lists five considerations for corporate social responsibility “, NewYork Times Magazine, 24. Sunday Section: Business and Finance, pp F14. Bolton RN, Drew JH (1991). A multistage model of consumer.

Bharuddin, M., Sahid, I., Noor, M., and Sulaiman, N. (2014), "Pesticide risk assessment: A study on Inhalation and Dermal Exposure to 2, 4-D and Paraquat among Malaysian Paddy Farmers. Journal of Environmental Science and Health Part B Pesticides Food Contaminants and Agricultural Wastes, 46(7), 600-607.

Bhattacharya, C. B., and Sen, S. (2004), "Doing better at doing good”,California Management Review, 47(1), 924.

Birindelli, G., et al. (2013), "On the drivers of corporate social responsibility in banks: evidence from an ethical rating model", Journal of Management \& Governance, 1-38.

Boateng, H., and Abdul-Hamid, I. K. (2017), “An evaluation of corporate social responsibility communication on the websites of telecommunication companies operating in Ghana: Impression management perspectives", Journal of Information, Communication and Ethics in Society, 15(01), 17-31.

Bowen, H. R. (1953)," Social responsibilities of the businessman. New York, NY: Harper \& Row.

Carroll, A. B. (1999). Corporate social responsibility: Evolution of a definitional construct", Business and Society, 38(3), 268-295.

Carroll, A.B., and Shabana, K.M. (2010), "The business case for corporate social responsibility: a review of concepts, research and practice", International Journal of Management Reviews, 12(1), 85-105.

Carson, D. (1977), "Point of View; Companies as Heroes? Bah! Humbug!! “, New York Times Magazine. Sunday, Section: Business \& Finance. 94.

Castaldo, S., and Perrini, F. (2004). Corporate social responsibility, trust management and value creation. Paper presented at EGOS Colloquium on Trust in Hybrids, Ljubljana, Slovenia.

Castaldo, S., Perrini, F., Misani, N., and Tencati, A. (2009), "The missing link between corporate social responsibility and consumer trust: The case of fair trade products", Journal of Business Ethics, 84(1), 1-15.

Chang, Y.-H., and Yeh, C.-H. (2017), "Corporate social responsibility and customer loyalty in intercity bus services", Transport Policy, 59, 38-45.

Chih, H., Chih, H., and Chen,T. (2009), "On the Determinants of Corporate Social Responsibility: International Evidence on the Financial Industry", Journal of Business Ethics, 93, 115-135.

Chochol'áková, A., Gabčová, L., Belás, J., and Sipko, J. (2015), 'Bank Customers' Satisfaction, Customers' Loyalty and Additional Purchases of Banking Products and Services. A Case Study from the Czech Republic",Economics and Sociology, 8(3), 82-94. DOI: 10.14254/2071-789X.2015/8-3/6.

Chun, K., and Bang, W. (2016), "Effect of CSR on Customer Loyalty: Moderating Effect of Authenticity", International Journal of $u$ - and e-Service, Science and Technology, 9(5), 135-142.

Chung, K., Yu, J., Choi, M., and Shin, J. (2015), “The Effects of CSR on Customer Satisfaction and Loyalty in China: The Moderating Role of Corporate Image", Journal of Economics, Business and Management, 3(5), 542-547.

Di Matos, C., Henrique, J., and Rosa, F. (2014), "Customer reactions to service failure and recovery in the banking industry: The influence of switching costs", Journal of Services Marketing, 27(7). DOI: $10.1108 / J S M-01-2012-0019$.

Dolandson, (1983), "Constructing a social contract for business", In T. Donaldson \& P. Werhane (Eds.), Ethical issues in business: 153-165. New York: Oxford University Press.

Drucker, P. (2007), "Innovation and entrepreneurship: Practice and principles". http://www.fuqua.duke.edu/centers/case/documents/dees_SE.pdf.

Fatemifar, A., and Rahimzadeh, M. (2015), "Influence of Social Responsibility Perception on Orthodontic Clinics Clients' Satisfaction”, Iran J Ortho, 10(1). 
Fisher, B., Turner, R. K., and Morling, P. (2009), "Defining and classifying ecosystem services for decision making', Ecological Economics, 68(3), 643-653.

Frambach, R. T., and Nijssen, E. J. (2001), "Creating Customer Value Through Strategic Marketing Planning”, Boston/Dordrecht/ London: Kluwer Academic Publishers.

Galbrerth, J. (2009), "Building Corporate Social Responsibility Into Strategy", European Business Review,21(2), 109-27.

Godfrey, P., and Hatch, N. (2007), "Researching Corporate Social Responsibility: An Agenda for the 21st Century", Journal of Business Ethics, 70 (1), 87-99.

Grigoroudis, E., Oefanoudaki, E., and Zopounidis, C. (2012), "Strategic Performance Measurement in a Healthcare Organization: A Multiple Criteria Approach Based On Balanced Score Card”, Omega, 40(1), 104-119.

Guo, J., Sun, L., and Li, X. (2009), “Corporate Social Responsibility Assessment of Chinese Corporation”, Int. J. Bus. Manage. 4 (4), 54-57.

Gupta, S. (2002), "Strategic Dimensions of Corporate Image: Corporate Ability and Corporate Social Responsibility as Sources of Competitive Advantage via Differentiation“. (PhD), Temple University. ProQuest Digital Dissertations database (UMI 3057076).

Hafeez, S., and Muhammed, B. (2012), "The Impact of Service Quality, Customer Satisfaction and Loyalty Programs On Customer's Loyalty: Evidence from Banking Sector of Pakistan”, International Journal of Business and Social Science, 3(6), 200-209

Hammed, R., Rehman, K., Ullah, I. (2017), "Corporate Social Responsibility and Consumer Evaluations with Mediating Effect of Marketing Communication: A Pakistani Telecommunication Perspective", Economics, Business and Management, XI (3), 202-230.

Hart, SL. (1995), “A Natural-Resource-Based View of the Firm”, Acad. Manage, 20, 986-1014.

Hart, SL., Mark, B., and Milstein, C. (2003), "Creating Sustainable Value”, Acad. Manage, 17(2), 56-69.

Hartmann, M. (2011), "Corporate Social Responsibility in the Food Sector", European Review of Agricultural Economics, 38(3), 297-324. doi: 10.1093/ erae/jbr031.

Hassan, Z., Nareeman, A., and Pauline, N. (2013), "Impact of CSR Practices on Customer Satisfaction and Retention: An Empirical Study on Foreign MNCs in Malaysia", International Journal of Accounting and Business Management, 1(2), 61-81.

Hollenbeck, C., and Kailkati, A. (2012), "Consumers' Use of Brands to Reflect Their Actual and Ideal Selves on Facebook", International Journal of Research In Marketing, 29(4), 395-405.

Hosaini, F., and Sofian, S. (2015), "The Influence of Corporate Social Responsibility on Customer Perspective in Private Universities", International Journal of Economics and Financial Issues, 5 Special Issue, 257-263.

Hull, C., and Rothenberg, S. (2008), "Firm Performance: the Interactions of Corporate Social Performance with Innovation and Industry Differentiation",Strategic Management Journal,29(7),781-789. https://doi.org/10.1002/smj.675

Humaidan, A. (2016), "The Effect of Corporate Social Responsibility on Customers' Satisfaction of Cellular Communications Companies: A Field Study From the Perspective of the Students of the University of Jordan”, British Journal of Marketing Studies, 4(4), 1-15.

IBM. Annual report. 2008.

Irhsad, A., Rahim, A., Khan, M., Khan, M. (2017), “The Impact of Corporate Social Responsibility on Customers Satisfaction and Customers Loyalty, Moderating Effect of Corporate Image (Evidence From Pakistan)", City University Research Journal, Special Issue, AIC, 63-73.

Jones, T.M. (1980), “Corporate Social Responsibility Revisited, Redefined”, California Management Review, (spring) 59-67.

Khan, M., and Fasih, M. (2014), "Impact of Service Quality on Customer Satisfaction and Customer Loyalty: Evidence from Banking Sector”, Pakistan Journal of Commerce and Social Sciences, 8(2), 331-354.

Kiran, R., and Sharma, A. (2011), "Corporate Social Responsibility: A Corporate Strategy for New Business Opportunities', Journal of International Business Ethics, 4(1), 10-17.

Klassen, R., and McLaughlin, C. (1996), “The Impact of Environmental Management on Firm Performance”, Management Science, 42(8), 1199-1214.

Kline, P. (2013), "Handbook of Psychological Testing”, London, England: Routledge.

Lafferty, B., and Goldsmith, R. (2005), "Corporate Credibility's Role in Consumers' Attitudes and Purchase Intentions When a High Versus a Low Credibility Endorser Is Used in the Ad", Journal of Business Research, 44(2), 109-116.

Lafi, K., and Al Sufy F.(2012), "Corporate Social Responsibility Associated With Customer Satisfaction and Financial Performance a Case Study with Housing Banks in Jordan", International Journal of Humanities and Social Science,2(15), 102-115.

Lam, A. (2016), “The impact of corporate social responsibility on customer loyalty: a study of the banking 
industry in Hong Kong: , PhD Dissertation, Edinburgh Business School, Heriot-Watt University.

Lam, H., and Khare, A. (2010), "HR's Crucial Role for Successful CSR." Journal of International Business Ethics,3(2), 3-15.

Lee, K.-H., and Shin, D. (2010), “Consumers' Responses to CSR Activities: The Linkage between Increased Awareness and Purchase Intention", Public Relations Review, 36(2), 193-195. doi: 10.1016/j.pubrev.2009.10.014.

Lee, Y.T., and Moon, J.Y. (2008), an Exploratory Study on the Balanced Score Card Model of Social Enterprise. Asian Journal on Quality, 9(2), 11-30.

Lichtenstein, D., Drumwright, M., and Braig, B. (2004), "The Effect of Corporate Social Responsibility on Customer Donations to Corporate-Supported Nonprofits”, Journal of Marketing, 68(4), 16-32.

Liu, Y., and Zhou, X. (2009), "Corporate Social Responsibility and Customer Loyalty: A Conceptual Framework", 6th International conference on service systems and service management, 8-10 June, Xiamen, PR China

Lockett, A., Moon, J., and Visser, W. (2006), "Corporate Social Responsibility in Management Research: Focus, Nature, Salience and Sources of Influence”, Journal of Management Studies, 43(1), 115-136.

Loureiro, S., Sardinha, D.,and Reiijnders, L. (2012), "The Effect of Corporate Social Responsibility on Consumer Satisfaction and perceived Value: The Case of The Automobile Industry Sector in Portugal", Journal of Cleaner Production,37, 172.

Maignan, I., and Ferrell, O. (2001), "Corporate Citizenship as a Marketing Instrument: Concepts, Evidence, and Research Directions", European Journal of Marketing, 35 (3/4), 457-484.

Mandhachitara, R., and Poolthong, Y. (2011), "A Model of Customer Loyalty and Corporate Social Responsibility", Journal of Services $\quad$ Marketing, $\quad 25(2), \quad$ 122133, https://doi.org/10.1108/08876041111119840.

Manne, GH. (1972), "Responsibility; Social Role of Business Could Lead to Market's Extinction", New York Times Magazine, 20. Sunday Section: Bus. Fin. F16.

Milo, T., and Garrido Morgado, A. (2012), "Corporate Reputation: A Combination of Social Responsibility and Industry, Corporate Social Responsibility and Environmental Management, 19(1). 11-31.

Min, CM. Ai, YJ, Choo, ACP, Wah, WP, and Yang, YC. (2012), "A Study of The Effect of Corporate Social Responsibility towards Consumer Buying Behavior", International Conference of Management, Economics and Finance, 15-16 October, Sarawak,https://www.researchgate.net/publication/249649009 _A_Study_Of_The_Effect_of_Corporate_Social_Responsibility_CSR_towards_Consumer_Buying_Behavi our, viewed $2 \overline{5}$ January $20 \overline{1} 6$.

Mohr, LA., Webb, DJ. And Harris, KE. (2001), "Do Consumers Expect Companies To Be Socially Responsible? The Impact of Corporate Social Responsibility on Buying Behavior.” J. Consum. Affairs, 35, 45-72.

Munari, L., Ielasi, F., and Bajetta, L. (2013), "Customer Satisfaction Management in Italian Banks", Qualitative Research in Financial Markets, 5(2), 139-160.

Murray, K., and Vogel, C. (1997), "Using a Hierarchy-of-Effects Approach to Gauge the Effectiveness of Corporate Social Responsibility to Generate Goodwill Toward the Firm: Financial versus Nonfinancial Impacts", Journal of Business Research, 38(2), 141-159.

Nasser, S. (2008), "The Impact of Banking Services Marketing On Customer Behavior: Comparative Study Between Private and Public Syrian Banks", PhD Thesis, Teshreen University. Aleppo.

Network for Business Sustainability, 2010.

Nochai, R., and Nochai, T. (2014), "The Effect of Dimensions of Corporate Social Responsibility on Consumers' Buying Behavior In Thailand: A Case Study in Bangkok”, International Conference on Economics, Social Science and languages, May 14- 15, Singapore. 42-46. http://docplayer.net/31103500The-effect-of-dimensions-ofcorporate-social-responsibility-on-consumers-buying-behavior-in-thailand-acase-study-inbangkok.html.

Onlaor, W., and Rotchanakitumnuai, S. (2010), "Enhancing Customer Loyalty Towards Corporate Social Responsibility of Thai Mobile Service Providers", World Academy of Science Engineering and Technology, 42.

Paulik, J., Kombo, F., and Ključnikov, A. (2015), "CSR as a driver of satisfaction and loyalty in commercial banks in the Czech Republic", Journal of International Studies, 8(3), 112-127.

Pérez, A., and Rodríguez Del Bosque, I. (2015), "Corporate Social Responsibility and Customer Loyalty: Exploring the Role of Identification, Satisfaction and Type of Company", Journal of Services Marketing, 29(1), 15-25. doi: 10.1108/ jsm-10-2013-0272.

Piercy, N., and Lane, N. (2009), "Corporate Social Responsibility: Impacts on Strategic Marketing and Customer Value', the Marketing Review, 9(4), 335-360. DOI: 10.1362/146934709X479917.

Porter, ME., and Claas Van Der Linde (1995), “Green and Competitive: Ending the Stalemate', Harv. Bus. Rev., $73,120-134$. 
Putra, P., Yasa, N. (2017), “The Role Of Corporate Image and Satisfaction: in Mediating the Effect of Corporate Social Responsibility On Customer Loyalty", Journal of Business and Management, 19(9), 10-17.

Rahim, RA., Jalaludin, FW. And Tajuddin, K. (2011), "Consumer Behavior towards Corporate Social Responsibility in Malaysia', Asian Academy of Management Journal, 16(1), 120-139.

Reichheld, F. F., and Schefter, P. (2000), "E-Loyalty: Your Secret Weapon on the Web', Harvard Business Review, 78(4), 105-113.

Safi, A., and Ramay, MI. (2013), "Corporate Social Responsibility and Consumer Behavior: a Study from Pakistan”, Information Management and Business Review, 5(4), 194-202.

Saleem, F., Goipnath, C. (2015), "Corporate Social Responsibility and Customer Behavior: A Developing Country Perspective", the Lahore Journal of Business, 1(4), 1-22.

Saleh, MHT. Ebeid, AY. And Abdelhameed, TA. (2015), "Customers' Perception of Corporate Social Responsibility (CSR): It's Impact on Word Of Mouth and Retention”, Innovative Marketing, 11(2), 49-55.

Sekaran, U. (2003), "Research Methods for Business: A Skill-Building Approach", 4th Edition, John Wiley \& Sons, New York.

Sen, S., Bhattacharya, C., and Korschum., D. (2006), "The Role of Corporate Social Responsibility in Strengthening Multiple Stakeholder Relationships: A Field Experiment” , Journal of the Academy of Marketing science, 34(2), 158-166.

Servaes, H., and Tamayo, A. (2013), "The Impact of Corporate Social Responsibility of Firm Value: The Role of Customer Awareness", Management Science, 59 (5), 1045-1061.

Sindhu, M., Arif, M. (2017), "Corporate Social Responsibility and Loyalty: Intervening Influence of Customer Satisfaction and Trust”, Cogent Business \& Management, 4, 1-10.

Smith, N. C. (2003), “Corporate social responsibility: Not Whether, But How “, Working Paper No. 03-701. London: London Business School, Center for Marketing.

Soana, M. G. (2011), "The Relationship between Corporate Social Performance and Corporate Financial Performance in the Banking Sector', Journal of Business Ethics, 104(1), 133-148.

Staudt, S., Shao, C., Dubinsky, A., and Wilson, P. (2014), "Corporate Social Responsibility, Perceived Customer Value, and Customer- Based Brand Equity: A Cross-National Comparison', Journal of Strategic Innovation and Sustainability, 10(1), 65-87.

Strandberg, C. (2009), "The Role of Human Resource Management in Corporate Social Responsibility", Issue Brief and Roadmap.

Terpstra, M., and Verbeeten, F. (2014), "Customer satisfaction: Cost driver or value driver? Empirical evidence from the financial services industry", European Management Journal, 32(3), 499-508.

Uddin, R., and Rahman, M. (2015), "The Impact of Corporate Social Responsibility on Firm Financial Performance, "Journal of Business Studies, XXXVI (3), 203-217.

Valor, C., De la Cuesta, G., (2003), "Responsabilidad Social de la Empresa: Concepto, Medición y Desarrollo en España", Boletín Económico ICE (2755), 7-20

World Business Council for Sustainable Development (WBCSD). (2004), “Corporate Social Responsibility: Meeting changing expectations".

Wu, M.-W., and C.-H. S. (2013), "Corporate Social Responsibility in the Banking Industry: Motives and Financial Performance", Journal of banking and Finance, 37(9), 3529-3547.

Wulleman, M., and Hudon, M. (2015), "Models of Social Entrepreneurship: Empirical Evidence from Mexic", Journal of Social Entrepreneurship, 7(2), 162-188.

Xie, X., Jia, Y., Meng, X., \& Li, C. (2017), “Corporate Social Responsibility, Customer Satisfaction, and Financial Performance: The Moderating Effect of the Institutional Environment in Two Transition Economies", Journal of Cleaner Production, 150, 26-39.

Yeung, S. (2011), "The Role of Banks in Corporate Social Responsibility", Journal of Applied Economics and Business Research, 1(2), 03-115. 